ISSN 0258-7122 (Print), 2408-8293 (Online)

Bangladesh J. Agril. Res. 42(1): 87-102, March 2017

\title{
DETERMINATION OF THE FREQUENCY AND DENSITY OF WEED SPECIES IN APPLE ORCHARDS IN KAHRAMANMARAS REGION OF TURKEY
}

\author{
TAMER ÜSTÜNER ${ }^{1}$
}

\begin{abstract}
A study was carried out in Kahramanmaras region of Turkey during 2012-13 having ten subregions namely, Afsin, Andırın, Caglayancerit, Ekinozu, Elbistan, Göksun, Center, Nurhak, Pazarcık and Türkoglu to determine the range, density and frequency of weeds in apple orchards. In the orchards 133 weed species from 31 families were determined. The average density of weeds was 112.49 plants $\mathrm{m}^{-2}$. The maximum density of weed species was found in Göksun (127.30 plants $\mathrm{m}^{-2}$ ) followed by Elbistan (126.13 plants $\mathrm{m}^{-2}$ ), Ekinozu (125.95 plants $\mathrm{m}^{-}$ ${ }^{2}$ ), Afsin (120.39 plants $\mathrm{m}^{-2}$ ), Center (117.94 plants $\mathrm{m}^{-2}$ ) and Caglayancerit (114.90 plants $\mathrm{m}^{-2}$ ), and the minimurn density was determined in Pazarc1k $\left(69.51\right.$ plants $\left.\mathrm{m}^{-2}\right)$. From the identified 133 weed species one species belonged to Pterydophyta, 21 species to Monocotyledoneae and 111 species to Dicotyledoneae. The average densities of the weed species over 10 subregions for Agropyron repens (L.) P. Beauv., Chenopodium album L., Bromus arvensis L. and Amaranthus retroflexus L. were found to be 13.76, 12.17, 12.10 and 10.76 plants $\mathrm{m}^{-2}$, respectively. With regard to frequency of occurrence, C. album L. was detected more than 56\% in six subregions excluding Andırın, Pazarcık, Türkoglu and Center; A. retroflexus L. more than 54\% in 7 subregions excluding Center, Pazarcık and Türkoglu and A. repens (L.) P. Beauv. more than $50 \%$ in 10 subregions. Frequency of occurance of Cynodon dactylon (L.) Pers. was observed 50.1, 50.9, 76.9\% in Afsin, Caglayancerit and Andırın, respectively and it was below 50\% in other 7 subregions. In terms of coverage, Alopecurus myosuroides Huds., A. retroflexus, A. repens, B. arvensis, C. album, Convolvulus arvensis L., C. dactylon and Lactuca serriola $\mathrm{L}$. were determined to be within the range of 20.2 to $48.2 \%$ in the study areas while the other species were below $20 \%$.
\end{abstract}

Keywords: Apple orchards, weed, density, frequency and general coverage.

\section{Introduction}

Turkey has huge fruit production potential due to its suitable ecological conditions and it ranks third after China and the USA with its 69,492,000 tons annual apple production (Anon., 2012). In apple farming of Turkey, Isparta ranks first with its 634,795 tons and then Karaman and Nigde with their production 388,400 and 317,271 tons, respectively. Kahramanmaras ranks $10^{\text {th }}$ in total land area of 56,060 ha and $12^{\text {th }}$ in total production of 97,673 tons (Anon., 2013).

${ }^{1}$ University of Kahramanmaras Sütcü İmam, Faculty of Agriculture, Department of Plant Protection, Kahramanmaras, Turkey. 
Many factors affect the productivity and quality of apple production one of the most important is weed. Generally apple orchards are fertilized heavily to get higher fruit yield and the weeds grown in the orchards rob up the fertilizer at a faster rate than the apple plants resulting in lower yields (Verma and Chauhan, 2013). The weeds also harbor insects, diseases and rodents and thus they lower the quality and quantity of apples and may increase the cost of production by causing difficulties during fruit harvest. It is reported that both narrow leaved and broad leaved weeds grow in the apple orchards of Turkey and other apple growing countries of the world and caused problems of orchard management (Zeki et al., 1994; Tepe, 1997; Yazlik and Tepe, 2001; Karaca and Guncan, 2003; Akbolat et al.,2007; Ustuner and Akyol, 2007; Junk et al.1997; Dastgheib and Frampton, 2000; Harington et al. 2000).

Since apple trees are poor competitors, their effective control becomes necessary. For this the weeds growing in any particular region must be properly identified. It is essential to know densities and frequencies of weed species grown in that region for their successful control. Besides, different weed species respond to different control methods. The challenge without identifying weed species will be unsuccessful and these will cause wastage of time, money and environmental pollution of herbicides. The most effective chemical control with weeds is the period when the weeds are 3-5 leaves. So determination of frequency occurrence, density, coverage of weeds and recognizing the life stages of those identified weeds will help selecting suitable control method. The survey study was therefore, conducted to identify weed species, and to determine their density, frequency of occurrence and coverage in Kahramanmaras region of Turkey.

\section{Materials and Method}

In the study, surveys made applied in the apple orchards in Kahramanmaras region (Center, Afsin, Andırın, Caglayancerit, Ekinozu, Elbistan, Göksun, Nurhak, Pazarcik and Türkoglu) in 2012-2013. Considering the distribution and density of the apple orchards in the region, 10 subregion were selected and the samples were obtained from these subregion. In the survey, it was considered at least $3 \mathrm{~km}$ among the gardens and the samples were obtained from the $15 \mathrm{~m}$ inside of the edge of the garden. Within the 1000 square meters, 4 frames (1 square fareme) were used and weeds were obtained and counted (Odum, 1971). The number of the weed in the 1 square meter were calculated by dividing of the total number of the each species in 1 square meter to the survey area.

Weed density was calculated via Density $=\mathrm{B} / \mathrm{n}$ formula (Guncan, 2001).

Here $B=$ Total weeds number in the sample, $n=$ Number of sample

In the evaluation, broad leaved weeds were considered as a whole plant while narrow leaved weed were considered as their stems and they were recorded on the survey cards. Species, numbers and coverages of weeds were recorded and 
frequency of occurrence, number of plant and general coverages of obtained data were calculated by using the following formulas:

Frequency of occurrence (F.O.): The per cent of the occurance of the weeds (\%) in an area.

Frequency of occurrence $(\%)=\mathrm{n} / \mathrm{mx} 100$

$\mathrm{n}$ : the number of the orchards containing species

M: total number of the orchards measured

Species Coverage (T.K.A.): It is expressed as average value that any species of weed covered surface.

G.K.A $(\%)=$ T.K.A./m

G.K.A.: General coverage, $\mathrm{m}$ : Total number of surveys

As suggested by Ustuner and Guncan (2002), density scale was used as follows:

A. High dense (average more than 10 in per square meter)

B. Dense (average between 1-10 in per square)

C. Low dense (average between 0.1-1 in per square meter)

D. Rarely observed (average between 0.01-0.1 in per square meter)

The surveyed areas were divided in 10 subregions (Table 1).

Table 1. Surveyed regions, the area of apple plantation and the number of frame in the study (Anon., 2013)

\begin{tabular}{l|c|c}
\hline \multicolumn{1}{c|}{ Subregions } & Apple plantation area (da) & The number of the frame \\
\hline Afsin & 4889 & 195 \\
Andırın & 182 & 60 \\
Caglayancerit & 3878 & 155 \\
Ekinözü & 5395 & 215 \\
Elbistan & 6149 & 245 \\
Göksun & 29881 & 500 \\
Center & 3667 & 146 \\
Nurhak & 1271 & 53 \\
Pazarcık & 83 & 33 \\
Türkoglu & 211 & 64 \\
Total & 55606 & 1666 \\
\hline
\end{tabular}

Because fruit trees are perennial, both summer and winter weeds grow in the apple orchards. Therefore, a total of 1666 samples were obtained in two different seasons. The first survey was made on April and May 2012-2013 while the second survey was made on August and September. 


\section{Results and discussion}

In the surveys of Kahramanmaras region's apple orchards a total of 133 species of weeds belonging to 31 families including 1 pterydophyta, 21 monocotyledoneae and 111 dicotyledoneae and $112.49\left(\right.$ plants $\left./ \mathrm{m}^{2}\right)$ were detected (Table 2).

Table 2. Number of families and weed species found in Kahramanmaras region

\begin{tabular}{ccc}
\hline Phylum/Subclass & Number of families & Number of weed species \\
\hline Pterydophyta & 1 & 1 \\
Monocotyledoneae & 3 & 21 \\
Dicotyledoneae & 27 & 111 \\
\hline
\end{tabular}

The average density of weeds in unit area was 13.76 plants $\mathrm{m}^{2}$ for $A$. repens, 12.17 for C. album, 12.10 for B. arvensis, 10.76 for $A$. retroflexus and it was high in density. 9.25 for $C$. dactylon, 9.06 for A. myosuroides, 6.80 for $C$. arvensis, 4.54 for D. glomerata, 4.41 for B. tectorum, 3.94 for L. serriola, 2.50 for $S$. viridis, 2.28 for $D$. sangunialis, 2.11 for L. temulentum, 1.99 for $S$. halepense, 1.33 for $C$. draba ssp draba, 1.25 for A. cylindrica, 1.07 for $C$. arvense, 1.04 for C. galaticus and 1.03 for $M$. chamomilla was densely detected.

Table 3. Weed density, frequency of occurrence and general coverage of weeds in Kahramanmaras region

\begin{tabular}{|c|c|c|c|}
\hline Weed species & Density $\left(\right.$ plants $\left./ \mathrm{m}^{2}\right)$ & Frequency $(\%)$ & Coverage $(\%)$ \\
\hline Agropyron repens (L.) P.Beauv. & 13.76 & $>50$ & $20.2-48.2$ \\
\hline Chenopodium album $\mathrm{L}$. & 12.17 & $>56$ & $20.2-48.2$ \\
\hline Bromus arvensis $\mathrm{L}$. & 12.10 & $>50$ & $20.2-48.2$ \\
\hline Amaranthus retroflexus $\mathrm{L}$. & 10.76 & $>54$ & $20.2-48.2$ \\
\hline Cynodon dactylon (L.) Pers. & 9.25 & $>50$ & $20.2-48.2$ \\
\hline Alopecurus myosuroides Huds. & 9.06 & $>50$ & $20.2-48.2$ \\
\hline Convolvulus arvensis $\mathrm{L}$. & 6.80 & $<50$ & $20.2-48.2$ \\
\hline Dactylis glomerata L. & 4.54 & $<50$ & $<20$ \\
\hline Bromus tectorum $\mathrm{L}$. & 4.41 & $<50$ & $<20$ \\
\hline Lactuca serriola $\mathrm{L}$. & 3.94 & $<50$ & $20.2-48.2$ \\
\hline Setaria viridis (L.) P.Beauv. & 2.50 & $<50$ & $<20$ \\
\hline Digitaria sanguinalis (L) Scop. & 2.28 & $<50$ & $<20$ \\
\hline Lolium temulentum $\mathrm{L}$. & 2.11 & $<50$ & $<20$ \\
\hline Sorghum halepense (L.) Pers. & 1.99 & $<50$ & $<20$ \\
\hline Cardaria draba $\operatorname{ssp} d r a b a$ (L.) Desv. & 1.33 & $<50$ & $<20$ \\
\hline Aegilops cylindrica Host. & 1.25 & $<50$ & $<20$ \\
\hline Cirsium arvense (L.) Scop. & 1.07 & $<50$ & $<20$ \\
\hline $\begin{array}{l}\text { Convolvulus galaticus } \\
\text { ExChoisy. }\end{array}$ & 1.04 & $<50$ & $<20$ \\
\hline Matricaria chamomilla $\mathrm{L}$. & 1.03 & $<50$ & $<20$ \\
\hline
\end{tabular}


Frequency of occurrence of weeds in the region indicated that $C$. album was more than $56 \%$ in 6 subregions except for Andırın, Pazarcık, Türkoglu and Center. A. repens was more than $50 \%$ in 10 subregions. A. retroflexus was more than $54 \%$ in 7 subregions except from Center, Türkoglu and Pazarcik. C. dactylon was less than $50.1 \%$ in Afsin, $50.9 \%$ in Caglayancerit, $76.9 \%$ in Andirın and $50 \%$ in other 7 subregions while B. arvensis was less than $50 \%$ in Center subregion, more than $52 \%$ in the other 9 subregions. A. myosuroides was detected more than 50\% in Andırın, Center, Caglayancerit and Göksun and less than $50 \%$ in the other subregions. C. arvensis was only detected $55.6 \%$ in Center and less than $50 \%$ in the other subregions (Table 3). The coverages for $A$. myosuroides, A. retroflexus, A. repens, B. arvensis, C. album, C. arvensis, $C$. dactylon and L. serriola varied from 20.2 to $48.2 \%$, while it was less than $20 \%$ for other species.

\section{Afsin subregion}

In this subregion, $C$. album, A. repens, A. retroflexus, $C$.dactylon, B. arvensis, $A$. myosuroides and $D$. sanguinalis were determined high densely. $C$. arvensis, $C$. arvense, L. serriola, C. galaticus, M. chamomilla, A. cylindrica, B. tectorum, E. crus-galli, L. temulentum and $P$. rhoeas were determined densely (Table 4).

Table 4. Weed density, frequency of occurrence and general coverage of weeds in Afsin subregion

\begin{tabular}{l|c|c|c}
\hline \multicolumn{1}{c|}{ Weed species } & Density $\left(\right.$ plants $\left./ \mathrm{m}^{2}\right)$ & Frequency $(\%)$ & Coverage $(\%)$ \\
\hline Chenopodium album L. & 16.2 & 60.8 & 48.2 \\
Agropyron repens (L.) P.Beauv. & 15.8 & 50.4 & 27.9 \\
Amaranthus retroflexus L. & 13.7 & 57.6 & 32.6 \\
Cynodon dactylon (L.) Pers. & 12.6 & 50.1 & 20.3 \\
Bromus arvensis L. & 11.4 & 52.5 & 28.1 \\
Alopecurus myosuroides Huds. & 10.9 & 48.6 & 19.5 \\
Digitaria sanguinalis (L) Scop. & 10.5 & 39.2 & 11.8 \\
Convolvulus arvensis L. & 7.4 & 42.3 & 14.7 \\
Cirsium arvense (L.) Scop. & 2.6 & 0.9 & 9.1 \\
Lactuca serriola L. & 2.3 & 0.8 & 6.5 \\
Convolvulus galaticus Rost.Ex Choisy & 2.2 & 0.13 & 1.9 \\
Matricaria chamomilla L. & 2.1 & 0.45 & 1.1 \\
Aegilops cylindrica Host & 2.1 & 0.11 & 1.8 \\
Bromus tectorum L. & 1.7 & 0.15 & 2.0 \\
Echinochloa crus -galli (L.) P.Beauv. & 1.4 & 0.02 & 2.3 \\
Lolium temulentum L. & 1.2 & 0.23 & 1.4 \\
Papaver rhoeas L. & 1.2 & 0.6 & 2.2 \\
Others & 5.04 & - & - \\
Total & 120.34 & - & - \\
\hline
\end{tabular}


The maximum frequency of occurence for weed species was $60.8 \%$ for $C$. album, $52.5 \%$ for $B$. arvensis, $42.3 \%$ for $C$. arvensis, $57.6 \%$ for A. retroflexus, $50.4 \%$ for A. repens and $50.1 \%$.for $C$. dactylon. General coverage of weeds were $48.2 \%$ for C. album, $32.6 \%$ for A. retroflexus, $28.1 \%$ for B. arvensis, $27.9 \%$ for A. repens and $20.3 \%$ for $C$. dactylon.

\section{Andırın subregion}

In Andirın's apple orchards, A. repens, C. dactylon, D. glomerata, B. arvensis and $A$. myosuroides were determined high densely. C. arvensis, A. cylindrica, $E$. crus-galli, B. tectorum and S. viridis were determined densely (Table 5).

The maximum frequency of occurence of weed species were $81.4 \%$ for $A$. repens, $76.9 \%$ C. dactylon, $69.3 \%$ for D. glomerata, $63.2 \%$ for $B$. arvensis and $40.1 \%$ A. myosuroides. General coverage of weeds were $42.3 \%$ for A. repens, $35.6 \%$ for C. dactylon, $28.4 \%$ for D. glomerata and $24.8 \%$ B. arvensis.

Table 5. Weed density, frequency of occurrence and general coverage of weeds in Andurm subregion

\begin{tabular}{l|c|c|c}
\hline \multicolumn{1}{c}{ Weed species } & Density $\left(\right.$ plants $\left./ \mathrm{m}^{2}\right)$ & Frequency(\%) & Coverage $(\%)$ \\
\hline Agropyron repens $(\mathrm{L}$.$) P.Beauv.$ & 19.8 & 81.4 & 42.3 \\
Cynodon dactylon (L.) Pers. & 15.46 & 76.9 & 35.6 \\
Dactylis glomerata L. & 13.3 & 69.3 & 28.4 \\
Bromus arvensis L. & 12.5 & 63.2 & 24.8 \\
Alopecurus myosuroides Huds. & 10.4 & 40.1 & 19.2 \\
Convolvulus arvensis L. & 2.63 & 29.5 & 6.9 \\
Aegilops cylindrica Host. & 1.7 & 10.4 & 3.6 \\
Echinochloa crus galli (L.) P.Beauv. & 1.68 & 7.3 & 1.2 \\
Bromus tectorum L. & 1.4 & 5.6 & 1.1 \\
Setaria viridis (L.) Pal. Beauv. & 1.29 & 3.3 & 0.6 \\
Others & 5.76 & - & - \\
Total & 85.92 & - & - \\
\hline
\end{tabular}

\section{Caglayancerit subregion}

The weed species, B. tectorum, B. arvensis, C. album, A. myosuroides, A. repens, $A$ retroflexus and $C$. dactylon were determined high densely. $C$. arvensis, $D$. glomerata, Cuscuta campestris, L. temulentum and S. viridis were determined densely (Table 6).

The maximum frequency of occurence of weed species were $76.7 \%$ for $B$. tectorum, $73.3 \%$ for B. arvensis, $70.1 \%$ for $C$. album, $54.2 \%$ for A. retroflexus, $52.7 \%$ for $A$. myosuroides, $50.9 \%$ for $C$. dactylon and $50.3 \%$ for A. repens. General coverage of weeds were $47.3 \%$ for $B$. tectorum, $41.2 \%$ for $C$. album, $40.8 \%$ for $B$. arvensis, $35.2 \%$ for A. retroflexus, $28.9 \%$ for $C$. dactylon and $26.3 \%$ for $A$. repens. 
Table 6. Weed density, frequency of occurrence and general coverage of weeds in Caglayancerit subregion

\begin{tabular}{l|c|c|c}
\hline \multicolumn{1}{c|}{ Weed species } & Density $\left(\right.$ plants $\left./ \mathrm{m}^{2}\right)$ & Frequency(\%) & Coverage(\%) \\
\hline Bromus tectorum L. & 18.8 & 76.7 & 47.3 \\
Bromus arvensis L. & 14.61 & 73.3 & 40.8 \\
Chenopodium album L. & 12.90 & 70.1 & 41.2 \\
Alopecurus myosuroides Huds & 11.23 & 52.7 & 22.5 \\
Agropyron repens (L.) P.Beauv. & 10.46 & 50.3 & 26.3 \\
Amaranthus retroflexus L. & 10.23 & 54.2 & 35.2 \\
Cynodon dactylon (L.) Pers & 10.12 & 50.9 & 28.9 \\
Convolvulus arvensis L. & 6.28 & 41.8 & 25.6 \\
Dactylis glomerata L. & 2.47 & 11.9 & 3.8 \\
Cuscuta campestris Yuncker & 2.4 & 9.45 & 0.24 \\
Lolium temulentum L. & 1.41 & 5.6 & 2.3 \\
Setaria viridis (L.) Pal. Beauv. & 1.35 & 3.8 & 1.2 \\
Others & 12.64 & - & - \\
Total & 114.90 & - & - \\
\hline
\end{tabular}

\section{Ekinözü subregion}

In this subregion's apple orchards, C. album, A. retroflexus, B. arvensis, A.repens, $C$. dactylon and A. myosuroides were determined high densely. $C$. arvensis, S. viridis, L. serriola, C. draba ssp draba, C. galaticus, A. cylindrica, E. crus-galli, B. tectorum, C. arvense and Amaranthus blitoides were determined densely (Table 7).

Table 7. Weed density, frequency of occurrence and general coverage of weeds in Ekinozu subregion

\begin{tabular}{lc|cc}
\hline \multicolumn{1}{c}{ Weed species } & Density $\left(\right.$ plants $\left./ \mathrm{m}^{2}\right)$ & Frequency(\%) & Coverage $(\%)$ \\
\hline Chenopodium album L. & 21.8 & 65.4 & 46.8 \\
Amaranthus retroflexus L. & 18.7 & 60.7 & 41.3 \\
Bromus arvensis L. & 15.4 & 58.2 & 30.4 \\
Agropyron repens (L.) P.Beauv. & 13.8 & 50.1 & 22.6 \\
Cynodon dactylon (L.) Pers & 12.9 & 46.7 & 23.5 \\
Alopecurus myosuroides Huds & 10.1 & 43.5 & 28.4 \\
Convolvulus arvensis L: & 8.3 & 42.9 & 29.2 \\
Setaria viridis (L.) Pal. Beauv. & 5.3 & 16.3 & 12.4 \\
Lactuca serriola L. & 4.9 & 15.2 & 10.3 \\
Cardaria draba Ssp draba (L.) Desv. & 1.9 & 10.4 & 4.8 \\
Convolvulus galaticus Rost.Ex Choisy. & 1.6 & 0.24 & 3.9 \\
Aegilops cylindrica Host. & 1.5 & 0.15 & 3.0 \\
Echinochloa crus galli (L.) P.Beauv. & 1.4 & 0.23 & 2.2 \\
Bromus tectorum L. & 1.3 & 0.16 & 0.8 \\
Cirsium arvense (L.) Scop. & 1.1 & 0.4 & 2.0 \\
Amaranthus blitoides S.Wats. & 1.0 & 0.11 & 1.2 \\
Others & 4.95 & - & - \\
Total & 125.95 & - & - \\
\hline
\end{tabular}


The maximum frequency of occurence of weed species were $65.4 \%$ for $C$. album, $60.7 \%$ for A. retroflexus, $58.2 \%$ for B. arvensis, $50.1 \%$ for A. repens and $46.7 \%$ for $C$. dactylon. General coverage of weeds were $46.8 \%$ for $C$. album, $41.3 \%$ for A. retroflexus, $30.4 \%$ for B. arvensis, $29.2 \%$ for $C$. arvensis and $28.4 \%$ for $A$. myosuroides.

\section{Elbistan subregion}

In Elbistan, C. album, B. arvensis, A. retroflexus, A. repens, L. serriola, $C$. dactylon and $A$. myosuroides were determined high densely whereas $C$. arvensis, L. temulentum, C. draba ssp draba, A. cylindrica, C. arvense and P. lanceolata were determined densely (Table 8 ).

The maxiumum frequency of occurence of weed species were $73.6 \%$ for $C$. album, $65.8 \%$ for $B$. arvensis, $62.4 \%$ for A. retroflexus, $51.7 \%$ for $A$. repens and $44.2 \%$ for $L$. serriola. General coverage of weeds were $39.6 \%$ for C. album, $30.2 \%$ for $B$. arvensis, $29.8 \%$ for $A$. retroflexus, $26.1 \%$ for $C$. arvensis and $25.4 \%$ for $A$. repens.

Table 8. Weed density, frequency of occurrence and general coverage of weeds in Elbistan subregion

\begin{tabular}{lc|c|c}
\hline \multicolumn{1}{c|}{ Weed species } & Density $\left(\right.$ plants/m $\left./ \mathrm{m}^{2}\right)$ & Frequency $(\%)$ & Coverage $(\%)$ \\
\hline Chenopodium album L. & 19.40 & 73.6 & 39.6 \\
Bromus arvensis L. & 14.62 & 65.8 & 30.2 \\
Amaranthus retroflexus L. & 14.43 & 62.4 & 29.8 \\
Agropyron repens (L.) P.Beauv. & 13.25 & 51.7 & 25.4 \\
Lactuca serriola L. & 10.62 & 44.2 & 21.3 \\
Cynodon dactylon (L.) Pers & 10.30 & 38.5 & 20.2 \\
Alopecurus myosuroides Huds & 10.11 & 36.3 & 19.6 \\
Convolvulus arvensis L. & 9.8 & 35.2 & 26.1 \\
Convolvulus galaticus Rost.Ex Choisy & 3.4 & 0.2 & 2.4 \\
Lolium temulentum L. & 3.3 & 18.9 & 8.2 \\
Cardaria draba ssp draba (L.) Desv. & 3.2 & 15.3 & 7.9 \\
Aegilops cylindrica Host. & 2.8 & 4.3 & 4.5 \\
Cirsium arvense (L.) Scop. & 2.1 & 10.5 & 6.3 \\
Plantago lanceolata L. & 1.3 & 0.96 & 2.1 \\
Others & 7.50 & - & - \\
Total & 126.13 & - & - \\
\hline
\end{tabular}

\section{Göksun subregion}

The weed species, A. repens, A. retroflexus, C. album, B. arvensis, A. myosuroides, $L$. serriola, $C$. dactylon, $L$. temulentum, D. glomerata were detected high densely whereas $C$. arvensis, D. carota, A. cylindrica, C. draba ssp draba, $S$. viridis, D. sanguinalis, B. tectorum, P. lanceolata, C. arvense, $C$. galaticus and $P$. media were determined densely (Table 9). 
The most frequency of occurence of weed species were C. album $71.4 \%, A$. retroflexus \%70.9, B. arvensis L. $69.3 \%$, A. repens $68.6 \%$ and A. myosuroides $\% 54.8$. General coverage of weeds were A. repens $43.2 \%$, A. retroflexus $38.1 \%$, C. album $33.4 \%$, B. arvensis L. $32.5 \%$, C. arvensis L. $30.0 \%$ and A. myosuroides $21.6 \%$ rate.

Table 9. Weed density, frequency of occurrence and general coverage of weeds in Göksun subregion

\begin{tabular}{|c|c|c|c|}
\hline Weed species & Density (plants $/ \mathrm{m}^{2}$ ) & Frequency $(\%)$ & Coverage $(\%)$ \\
\hline Agropyron repens (L.) P.Beauv. & 21.5 & 68.6 & 43.2 \\
\hline Amaranthus retroflexus L. & 18.9 & 70.9 & 38.1 \\
\hline Chenopodium album $\mathrm{L}$. & 17.8 & 71.4 & 33.4 \\
\hline Bromus arvensis $\mathrm{L}$. & 16.9 & 69.3 & 32.5 \\
\hline Alopecurus myosuroides Huds. & 11.2 & 54.8 & 21.6 \\
\hline Lactuca serriola $\mathrm{L}$. & 11.0 & 49.9 & 20.8 \\
\hline Cynodon dactylon (L.) Pers. & 10.8 & 38.5 & 19.9 \\
\hline Lolium temulentum $\mathrm{L}$. & 10.7 & 32.1 & 18.4 \\
\hline Dactylis glomerata L. & 10.4 & 28.7 & 17.3 \\
\hline Convolvulus arvensis $\mathrm{L}$. & 8.6 & 47.2 & 30.0 \\
\hline Daucus carota $\mathrm{L}$. & 4.6 & 13.10 & 8.2 \\
\hline Aegilops cylindrica Host. & 4.1 & 10.8 & 7.3 \\
\hline $\begin{array}{l}\text { Cardaria draba ssp draba (L.) } \\
\text { Desv. }\end{array}$ & 3.92 & 9.2 & 6.5 \\
\hline Setaria viridis (L.) P.Beauv. & 3.8 & 7.5 & 6.2 \\
\hline Digitaria sanguinalis (L.) Scop. & 3.1 & 8.6 & 6.1 \\
\hline Bromus tectorum $\mathrm{L}$. & 2.6 & 3.4 & 5.9 \\
\hline Plantago lanceolata $\mathrm{L}$. & 2.30 & 3.3 & 4.1 \\
\hline Sorghum halepense (L.) Pers. & 2.30 & 1.4 & 0.3 \\
\hline Cirsium arvense(L.) Scop. & 1.9 & 2.8 & 3.4 \\
\hline Convolvulus galaticus Rost.Ex Choisy & 1.7 & 2.6 & 3.8 \\
\hline Plantago media $\mathrm{L}$. & 1.1 & 2.4 & 2.0 \\
\hline Others & 8.08 & - & - \\
\hline Total & 177.30 & - & - \\
\hline
\end{tabular}

\section{Center subregion}

In Center subregion's apple orchards, A. repens (L.) P.Beauv., A. myosuroides and $C$. arvensis were determined high densely whereas B. tectorum L., C. album, A. retroflexus, $C$. dactylon, $D$. sanguinalis, D. glomerata, $S$. halepense, $C$. campestris, A. sterilis, P. trivialis, C. solstitialis subsp. solstitialis, S. viridis, $C$. draba ssp draba, A. repens (L.) DC., B. arvensis, M. chamomilla, C. rotundus and $P$. australis species were determined densely (Table 10). 
The maximum frequency of occurence of weed species were $58.1 \%$ for $A$. repens (L.) P.Beauv, \%57.2 for A. myosuroides, $55.6 \%$ for $C$. arvensis (L.) Pers., $53.7 \%$ for B. tectorum L. and $42.5 \%$ for $C$. album. But general coverage of weeds were $30.3 \%$ for $C$. album, $30.2 \%$ for $C$. arvensis (L.) Pers., $28.3 \%$ for $A$. retroflexus, $24.7 \%$ for $B$. tectorum and A. myosuroides $22.6 \%$ rate.

Table 10. Weed density, frequency of occurrence and general coverage of weeds in Center subregion

\begin{tabular}{|c|c|c|c|}
\hline Weed species & Density (plants $\left./ \mathrm{m}^{2}\right)$ & Frequency $(\%)$ & Coverage $(\%)$ \\
\hline Agropyron repens (L.) P.Beauv. & 11.4 & 58.1 & 20.4 \\
\hline Alopecurus myosuroides Huds. & 10.9 & 57.2 & 22.6 \\
\hline Convolvulus arvensis $\mathrm{L}$. & 10.8 & 55.6 & 30.2 \\
\hline Bromus tectorum $\mathrm{L}$. & 9.74 & 53.7 & 24.7 \\
\hline Chenopodium album $\mathrm{L}$. & 8.2 & 42.5 & 30.3 \\
\hline Amaranthus retroflexus $\mathrm{L}$. & 7.6 & 25.3 & 28.3 \\
\hline Cynodon dactylon (L.) Pers. & 7.3 & 28.9 & 16.4 \\
\hline Digitaria sanguinalis (L) Scop. & 5.6 & 8.4 & 2.1 \\
\hline Dactylis glomerata L. & 5.4 & 28.7 & 12.8 \\
\hline Sorghum halepense (L.) Pers. & 4.9 & 34.3 & 8.9 \\
\hline Avena sterilis L. & 2.1 & 12.4 & 3.5 \\
\hline Poa trivialis L. & 2.0 & 6.2 & 0.89 \\
\hline Cuscuta campestrisYuncker & 1.82 & 9.3 & 0.3 \\
\hline Centaurea solstitialis subsp. solstitialis & 1.72 & 1.3 & 0.92 \\
\hline Setaria viridis (L.) P. Beauv. & 1.68 & 1.4 & 1.03 \\
\hline Cardaria draba ssp draba (L.) Desv. & 1.59 & 18.4 & 2.8 \\
\hline Acroptilon repens (L.) DC. & 1.53 & 2.1 & 0.5 \\
\hline Bromus arvensis $\mathrm{L}$. & 1.4 & 22.8 & 2.1 \\
\hline Matricaria chamomilla $\mathrm{L}$. & 1.25 & 20.1 & 1.6 \\
\hline Cyperus rotundus $\mathrm{L}$. & 1.2 & 17.9 & 1.6 \\
\hline $\begin{array}{l}\text { Phragmites australis (cav.) Trin. Ex } \\
\text { steudel }\end{array}$ & 1.06 & 3.2 & 2.8 \\
\hline Others & 18.75 & - & - \\
\hline Total & 117.94 & - & - \\
\hline
\end{tabular}

\section{Nurhak subregion}

In this area, B. arvensis, A. repens (L.) P.Beauv., D. glomerata, A. retroflexus, $C$. album and A. myosuroides were determined high densely. L. serriola, S. viridis, C. dactylon, C. arvensis, C. solstitialis subsp. solstitialis, E. crus-galli, $L$. temulentum and $M$. longifolia were determined densely (Table 11).

The maximum frequency of occurence of weed species were $60.6 \%$ for $B$. arvensis, $59.4 \%$ for A. retroflexus, $56.2 \%$ for $C$. album, $54.3 \%$ for A. repens and $52.1 \%$ for $D$. glomerata. General coverage of weeds were $32.6 \%$ for $B$. arvensis, $34.8 \%$ for A. retroflexus, $29.3 \%$ for C. album, $26.5 \%$ for D. glomerata and $23.4 \%$ for A.repens. 
Table 11. Weed density, frequency of occurrence and general coverage of weeds in Nurhak subregion

\begin{tabular}{lc|c|c}
\hline \multicolumn{1}{c|}{ Weed species } & Density $\left(\right.$ plants $\left./ \mathrm{m}^{2}\right)$ & Frequency $(\%)$ & Coverage $(\%)$ \\
\hline Bromus arvensis L. & 12.8 & 60.6 & 32.6 \\
Agropyron repens (L.) P.Beauv. & 11.2 & 54.3 & 23.4 \\
Dactylis glomerata L. & 11.0 & 52.1 & 26.5 \\
Amaranthus retroflexus L. & 10.7 & 59.4 & 34.8 \\
Chenopodium album L. & 10.5 & 56.2 & 29.3 \\
Alopecurus myosuroides Huds. & 10.3 & 43.8 & 20.5 \\
Lactuca serriola L. & 5.2 & 27.3 & 12.7 \\
Setaria viridis (L.) P.Beauv. & 5.0 & 10.2 & 9.6 \\
Cynodon dactylon (L.) Pers. & 4.7 & 13.5 & 8.3 \\
Convolvulus arvensis L. & 3.8 & 20.7 & 7.2 \\
Centaurea solstitialis subsp. solstitialis & 2.64 & 2.5 & 1.1 \\
Echinochloa crus galli (L.) P.Beauv. & 1.5 & 2.1 & 1.6 \\
Lolium temulentum L. & 1.28 & 4.6 & 4.5 \\
Mentha longifolia (L.) Hudson. & 1.12 & 1.3 & 2.1 \\
Others & 6.01 & - & - \\
Total & 97.75 & - & - \\
\hline
\end{tabular}

\section{Pazarcık subregion}

The weed species, B. arvensis, A. repens (L.) P.Beauv. were determined high densely. B. tectorum, C. dactylon, C. album, A. retroflexus, C. arvensis, A. myosuroides, S. halepense, D. glomerata, C. solstitialis subsp. solstitialis, D. sanguinalis, $S$. viridis, L. temulentum, L. amplexicaule and A. columnaris species were determined densely (Table 12).

Table 12. Weed density, frequency of occurrence and general coverage of weeds in Pazarcık subregion

\begin{tabular}{l|c|c|c}
\hline \multicolumn{1}{c|}{ Weed species } & Density $\left(\right.$ plants $\left./ \mathrm{m}^{2}\right)$ & Frequency $(\%)$ & Coverage $(\%)$ \\
\hline Bromus arvensis $\mathrm{L}$. & 10.5 & 54.9 & 30.3 \\
Agropyron repens (L.) P.Beauv. & 10.1 & 53.6 & 25.1 \\
Bromus tectorum L. & 7.2 & 38.3 & 19.8 \\
Cynodon dactylon (L.) Pers. & 5.3 & 32.8 & 17.2 \\
Chenopodium album L. & 4.9 & 30.4 & 16.4 \\
Amaranthus retroflexus L. & 4.3 & 25.7 & 19.3 \\
Convolvulus arvensis L. & 3.2 & 20.3 & 16.0 \\
Alopecurus myosuroides Huds. & 2.4 & 8.2 & 5.6 \\
Sorghum halepense (L.) Pers. & 2.1 & 9.2 & 4.7 \\
Dactylis glomerata L. & 1.6 & 9.6 & 3.2 \\
Centaurea solstitialis subsp. solstitialis & 1.4 & 4.1 & 2.4 \\
Digitaria sanguinalis (L.) Scop. & 1.3 & 3.9 & 2.9 \\
Setaria viridis $(\mathrm{L}$.$) P.Beauv.$ & 1.2 & 6.5 & 1.8 \\
Lolium temulentum L. & 1.19 & 2.1 & 1.6 \\
Lamium amplexicaule L. & 1.11 & 3.2 & 1.9 \\
Aegilops columnaris Zhuk. & 1.1 & 1.3 & 0.3 \\
Others & 10.61 & - & - \\
Total & 69.51 & - & - \\
\hline
\end{tabular}


The most frequency of occurence of weed species was $54.9 \%$ for $B$. arvensis, $53.6 \%$ for A. repens, $38.3 \%$ for B. tectorum, $32.8 \%$ for $C$. dactylon and $30.4 \%$ for $C$. album. General coverage of weeds were $30.3 \%$ for $B$. arvensis, $25.1 \%$ for A. repens, $19.8 \%$ for $B$. tectorum, $19.3 \%$ for A. retroflexus and $17.2 \%$ for $C$. dactylon.

\section{Türkoglu subregion}

In this region, $B$. arvensis, $S$. halepense ve A. repens (L.) P.Beauv. were determined high densely. C. album, A. retroflexus, $C$. arvensis, $S$. viridis, $L$. serriola, A. myosuroides, $C$. dactylon, M. chamomilla, D. sanguinalis, S. arvensis, $C$. rotundus, $S$. asper and D. glomerata were determined densely (Table 13).

The frequency of occurence of weed species were $\% 54.2$ for B. arvensis, $52.4 \%$ for $S$. halepense, $51.8 \%$ for A. repens, $43,9 \%$ for C. album and $37.3 \%$ for A. retroflexus. General coverage of weeds were $30.9 \%$ for B. arvensis, $29.4 \%$ for $S$. halepense, $28.2 \%$ for A. retroflexus, $25.1 \%$ for C. album and $24.6 \%$ for A. repens.

Table 13. Weed density, frequency of occurrence and general coverage of weeds in Türkoglu subregion

\begin{tabular}{lcccc}
\hline \multicolumn{1}{c}{ Weed species } & Density $\left(\right.$ plants $\left./ \mathrm{m}^{2}\right)$ & Frequency $(\%)$ & Coverage $(\%)$ \\
\hline Bromus arvensis L. & 10.9 & 54.2 & 30.9 \\
Sorghum halepense (L.) Pers. & 10.6 & 52.4 & 29.4 \\
Agropyron repens (L.) P.Beauv. & 10.3 & 51.8 & 24.6 \\
Chenopodium album L. & 9.2 & 43.9 & 25.1 \\
Amaranthus retroflexus L. & 8.1 & 37.3 & 28.2 \\
Convolvulus arvensis L. & 7.2 & 22.6 & 19.5 \\
Setaria viridis (L.) P.Beauv. & 3.4 & 14.1 & 12.2 \\
Lactuca serriola L. & 3.2 & 13.6 & 10.4 \\
Alopecurus myosuroides Huds. & 3.1 & 12.1 & 10.6 \\
Cynodon dactylon (L.) Pers. & 3.0 & 11.5 & 8.9 \\
Matricaria chamomilla L. & 2.5 & 10.2 & 6.4 \\
Digitaria sanguinalis (L) Scop. & 2.3 & 7.8 & 6.5 \\
Sinapis arvensis (L.) & 2.1 & 9.1 & 5.3 \\
Cyperus rotundus L. & 1.9 & 8.7 & 5.7 \\
Sonchus asper (L.) Hill. & 1.4 & 7.4 & 5.2 \\
Dactylis glomerata L. & 1.2 & 5.9 & 3.6 \\
Others & 8.74 & - & - \\
Total & 89.14 & - & - \\
\hline
\end{tabular}

Species and densities of the weeds found in the apple orchards of Kahramanmaras showed differences according to the subregions. Some species were distributed in all regions while some species were distributed regionally. $A$. 
repens (L.) P. Beauv. was determined at high density in the all subregions. $C$. album was observed as high dense in the subregions of Afsin, Caglayancerit, Ekinozu, Elbistan, Göksun and Nurhak while it was detected dense in the subregions of Center, Pazarcik and Türkoglu and it was found low dense in the Andırın. B. arvensis was high dense found in the subregions of Afsin, Caglayancerit, Ekinozu, Elbistan, Göksun, Nurhak, Pazarcık and Türkoglu while it was found dense in Andırın and Center subregion. Similarly, A.retroflexus was observed with high dense in the subregions of Afsin, Caglayancerit, Ekinozu, Elbistan, Göksun, Center, Nurhak and Türkoglu while it was observed dense in the Pazarcık and low dense in the Andırın. C. dactylon was detected as high dense in the subregions of Afsin, Andırın, Caglayancerit, Ekinozu, Elbistan and Göksun while it was determined as dense in the subregions of Center, Nurhak, Pazarcık and Türkoglu. A. myosuroides was detected as high dense in the subregions of Afsin, Caglayancerit, Ekinozu, Elbistan, Göksun, Center and Nurhak while it was found dense in the subregions of Andırın, Pazarcık and Türkoglu.

C. arvensis was found high dense in Center and Türkoglu, dense in Afsin, Andırın, Caglayancerit, Ekinozu, Elbistan, Göksun, Nurhak and Pazarcık. D. glomerata was found high dense in Andırın and Göksun, dense in Caglayancerit, Center, Pazarcik and Türkoglu, and it doesn't exist in Afsin, Ekinozu and Elbistan. B. tectorum was found high dense in Caglayancerit and Center, dense in Afsin, Andırın, Ekinözü, Göksun and Pazarcık, and low dense in Elbistan, Nurhak, and Türkoglu. L. serriola was found high dense in Elbistan and Göksun, dense in Afsin, Ekinozu, Nurhak, Türkoglu and low dense in Andırın, Caglayancerit, Center and Pazarcik. S. viridis was found dense in Andırın, Caglayancerit, Ekinözü, Göksun, Center, Nurhak, Pazarcık and low dense in Afsin and Elbistan. D. sanguinalis was found high dense in Afsin, dense in Göksun, Center, Pazarcık and Türkoglu and it doesn't exist in Andırın, Caglayancerit, Ekinözü, Elbistan and Nurhak. L. temulentum was high dense in Göksun, dense in Afsin, Caglayancerit, Elbistan, Nurhak and Pazarcık and low dense in Andırın, Ekinozu, Center and Türkoglu. S. halepense was high dense in Türkoglu, dense in Göksun, Center and Pazarckk, and it doesn't exist in Afsin, Andırın, Caglayancerit, Ekinozu, Elbistan and Nurhak. C. draba sp draba was found dense in Ekinozu, Elbistan, Göksun and Center, low dense in Afsin, Caglayancerit, Nurhak, Pazarcık and Türkoglu and rarely observed in Andırın. A. cylindrica was found dense in Afsin, Andırın, Ekinozu, Elbistan and Göksun, low dense in Caglayancerit, and it doesn't exist in Center, Nurhak, Pazarcık and Türkoglu. C. arvense was dense in Afsin, Ekinozu, Elbistan and Göksun, low dense in Caglayancerit, Center, Nurhak, Pazarcık and Türkoglu and low dense in Andırın. C. galaticus was found dense in Afsin, Ekinozu, Elbistan and Göksun, low dense in Andırın, Caglayancerit and Center and it doesn't exist in Nurhak and Pazarcık. M. chamomilla was found dense in Afsin, Center and Türkoglu, 
low dense in Caglayancerit, Ekinozu, Elbistan, Göksun, Nurhak, Pazarcık and Andırın.

Kahramanmaras region is located in Mediterranean region and Continental climate zones. Therefore, while Center, Pazarcık and Türkoglu subregions are located in the Mediterranean climate, Andırın and Caglayancerit are located in the transition climate. However, Göksun, Afsin, Elbistan, Nurhak and Ekinozu have a continental climate. The region have different soil structure types. The $\mathrm{pH}$ of the soil in the region varied from 7.06 to 8.33 and generally it was 7.60. Calcareous contents of the region were generally less than 5\% (Yilmaz et al., 2000).

The weed density in the Göksun subregion was found much more than that of the other subregion because it had 6 times larger apple orchards area than other subregions. Because Pazarckk subregion was the smallest apple orchads area, its weed density was found low. Determined density, frequency of occurance and coverage of the some species of weeds varied according to subregions. In this study, densities of the perennial plants with rhizome and stolon were especially found high.

Densities of Cyperus spp. and $P$. oleracea in the Mediterranean region were reperted as the most common weeds especially in the summer season (Kadioglu and Ulu, 1993). Frequency of occurrence of Stelleria media, M. chamomille, Oxalis spp., Poa annua and L. serriola were more than 50\% on March and April in the same study. In Aydin region, 47 weed species belonging to 20 families were reported by Ögüt and Boz (2007) and frequency of occurrence were 79.80\% for $S$. media, $63.60 \%$ for M. chamomilla, $55.50 \%$ for Oxalis corniculata, $52.80 \%$ for Poa annua and $50.0 \%$ for L. serriola in the dormand season. On the summer season, frequency of occurrence of $P$. oleracea, $C$. rotundus and Amaranthus spp. were $87.80,85.80$ and $63.30 \%$, respectively. Frequency of occurrence of $T$. terrstris, C. dactylon, C. arvensis, D. sanguinalis, L. serriola, C. album, E. crusgalli and $S$. halepense varied from 20 to $45 \%$ while the other weeds were in between 2 and $10 \%$ frequency of occurrence. The coverage of the weeds were $56.25 \%$ for $P$. oleracea, $52.70 \%$ for C. rotundus, $16.62 \%$ for $C$. dactylon, 16.54 $\%$ for Trifolium spp., $13.39 \%$ for D. sanguinalis, and $12.74 \%$ for Amaranthus spp. (Ögüt and Boz, 2007). A total of 47 weed species belonging to 19 families were identified on the apple orchards in Nigde region (Ustuner and Ustuner, 2011). In the survey studies in Isparta's apple orchards, densities of $A$. retroflexus, $P$. oleracea $\left(8.92\right.$ plants $\left.\mathrm{m}^{-2}\right)$ and Setaria verticillata were detected as $10.56 \%, 8.92 \%$ and $4.79 \%$, respectively. The coverage areas were $5.14 \%$ for $A$. retroflexus, $3.69 \%$ for Tribulus terrestris and $3.00 \%$ for $P$. oleracea. The most common weed species in the apple orchards were $83.33 \%$ for C. album, $C$. arvensis and P. oleracea, $77.78 \%$ for A. retroflexus and $77.22 \%$ for L. serriola (Kitis, 2011). 
Densities and frequency of occurrence of weeds in Turkey were reported by Kadıoğlu and Ulu (1993), Zeki et al., (1994), Tepe (1997), Yazlık and Tepe (2001), Karaca and Guncan (2003), Ustuner and Akyol (2007), Ögüt and Boz (2007) and Kitis (2011). The results of this studies were similar with our results. Majority of the weeds were A. repens (L.) P.Beauv., A. myosuroides, Amaranthus spp., B. tectorum, C. album, C. dactylon, $S$. viridis, D. glomerata, C. arvensis, $M$. chamomilla, L. serriola, $S$. halepense and D. sanguinalis. However, the species of Trifolium spp., Lolium perenne, Lotus corniculatus L., Taraxacum spp., $P$. annua, $P$. lanceolata, Stelleria media, Oxalis corniculata, P. oleracea, C. bursapastoris, C. rotundus, E. crus-galli and T. terrestris showed differencies according to the region. The reason of these differences is different climate due to conditions, irrigation systems, soil type and altitudes of the regions.

The results of the present study were also consistent with the results of the studies carried out different region in the world (Dastgheib and Frampton, 2000; Harrington et al., 2002; Hamma and Ibrahim, 2013; Verma and Chauhan, 2013). $A$. retroflexus, $A$. repens $C$. album and $C$. arvensis in the present study were similar with the species in the previous studies.

Some of the factors such as the altitude, soil structure, climate, irrigation system and plant communities of the region played a vital role in these similarities.

Consequently, densities, frequency of occurrence and coverage of the weeds may be different according to the subregion. These numerical values may also vary in the same region. The factors such as altitude, climate, soil structure, irrigation systems, tree corolla width (shadowing) and plantation area's size of the region may play a role in emerging of this variation.

\section{References}

Akbolat, D., K. Ekinci, S. Uysal and E. Onursal. 2007. The Effect of $\mathrm{Co}_{2}$ out of the ground widely used weed control in tillage weed growth in apple orchards. J. Agril. Machinery Sci. 3(2): 87-96.

Anonymous, 2012. Food and agriculture organization of the onited nations. http://faostat.fao.org/site/339/default.aspx.

Anonymous, 2013. The Amount of apple production according to province. www.tuik.gov.tr/bitkiselapp/bitkisel.zul,

Dastgheib, F. and C. Frampton. 2000. Weed management practices in apple orchards and vineyards in the South Island of New Zealand. N.Z.J. Crop Hort.Sci. 28:53-58.

Guncan, A. 2001. Weeds and principles, Selçuk univ. Agriculture faculty, Textbook., Konya.

Hamma, I. L. and U. Ibrahim. 2013. Weed management techniques of horticultural crops in Nigeria. American-Eurasian J. Agric. \& Environ. Sci. 13(3): 362-366.

Harrington, K. C., M. J. Hartley, A. Rahman and T. K. James. 2000. Strategies for controlling weeds in New Zealand apple orchards Thirteenth Australian weeds conference. Pp. 208-211. 
Jung, J.S., J.S. Lee and C. D. Cho1. 1997. Weed occurence in apple orchards in Korea. Weed absract, 47:20-22.

Kadioglu, I. and E. Ulug. 1993. Researchs on the determination of fruit nursery weeds in the Mediterranean region. Turkey I. Herbology congress, 3-5 February, Adana.

Karaca, M. and A. Guncan. 2003. Research on control of weeds were problem in young apple orchards Karaman region. Selçuk univ., Institute of science and technology, Plant protection department, Unpublished master's thesis, $64 \mathrm{Pp}$.

Kitis, Y.E. 2011. Determination of the species, density, coverage and frequency of the weeds in apple orchards in Isparta province. Turkey IV. Plant protection congress. 28-30 June 2011, Kahramanmaras.

Odum, E.P. 1971. Fundamentals of ecology. W.B. Saunders company, Philadelphia, London, Toronto.

Ögüt, D. and Ö. Boz. 2007. Determination of the weed species frequence and density in nursery growing areas in Aydın province. Turkish weed sci. 10(2):9.

Tepe, I. 1997. Weeds and control the problems of agriculture and non-agricultural areas in Turkey. Centennial univ., Publication No. 32. Agriculture faculty, Number Textbook of Plant Protection. 18: 102-103, Van.

Ustuner, T. and A. Guncan. 2002. A research on weed species which are problem, importance, biology of germination and control possibilties of them in potato fields in Nigde Province. Selçuk university, Graduate school of natural and Apllied science, $\mathrm{PhD}$ dissertation, Konya. $35 \mathrm{Pp}$.

Ustuner, T. and E. Akyol. 2007. Determination of the weed species, their observation frequencies and densities, in the apple orchards in Nigde province. Turkish weed sci. 10(1): 22 .

Ustuner, T. and M. Ustuner. 2011. Investigation on different mulch materials and chemical control for controlling weeds in apple orchard in Turkey. Scientific Research and Essays. 6(19): 3979-3985, Available online at http://www.academicjournals.org/SRE ISSN 1992-2248 @2011 Academic Journals.

Verma, M. L. and J. K. Chauhan. 2013. Eflect of integrated nutrient application on apple productivity and soil fertility in temperate zone of Himachal Pradesh. Int. J. Farm. Sci. 3(2): 19-27.

Yazlık, A. and I. Tepe. 2001. The Studies on weeds in apple and pear orchards in Van province and their distributions. Turkish Weed Sci. 4(1): 11.

Yılmaz, K., R. Gündogan and A. R. Demirkıran. 2000. Pedogenesis and classification of soils in Kahramanmaras province, Turkey. International symposium on desertification, ISD, Proceedings P. 517-524. Konya.

Zeki, C., T. Demir, S. Tokgönül and M. Kılıç. 1994. Integrated research, practice and training project in apple orchards. Project No: BKA-EM 10 TAGEM, Volume: II., Ankara. 